\title{
Evaluation of Haemato-Biochemical Parameters using Different Biomaterials in Fracture Healing of Dogs
}

\author{
Astha Chaurasia ${ }^{1 *}$, Shobha Jawre', Randhir Singh ${ }^{1}$, Apra Shahi ${ }^{1}$, \\ Rekha Pathak ${ }^{2}$, Babita Das ${ }^{1}$ and Naveen Kumar Verma ${ }^{2}$ \\ ${ }^{1}$ Department of Veterinary Surgery \& Radiology, NDVSU, Jabalpur, 482001, (MP), India \\ ${ }^{2}$ Division of Surgery, ICAR-IVRI, Izatnagar, Bareilly, 243122, (UP), India \\ *Corresponding author
}

\section{Keywords}

Fracture, Titanium pin, Decellularised bone chip graft, $\beta$ TCP, Haematobiochemical examination

Article Info

Accepted:

18 April 2019

Available Online:

10 May 2019

\section{A B S T R A C T}

The present study was conducted on 12 dogs of either, sex, breed, aged between 1-8 years brought to T.V.C.C, Jabalpur having a diaphyseal fracture in any of the long bones i.e. Humerus, femur and tibia. The dogs were randomly divided into three equal groups irrespective of breed and sex. The radiographs in two standard views were taken to diagnose the fracture and to select optimum titanium pins. In all the three groups, the diaphyseal fractures were repaired with internal fixation using titanium elastic pin. In group I, the fracture was repaired by using the titanium pin alone. In group II, along with internal fixation bone loss or bone gap in fractures site were filled by decellularised xenogeneic cancellous bone chip graft, while in group III, bone loss or gap at fracture site was filled and packed with granules of beta tricalcium phosphate ( $\beta$ - TCP). A 5 ml blood was collected from each animal on the day of surgery and at different time intervals up to 60th post-operative day for haemato-biochemical estimation. Haemato-biochemical parameters like haemoglobin, total erythrocyte count, total leucocyte counts and differential leukocyte count included neutrophil, lymphocyte, eosinophil, basophil and monocyte activity and serum calcium, phosphorus and alkaline phosphatase enzyme activity during fracture healing were analyzed and found that the above all haematobiochemical parameters on different post-operative days provided much help in assessing source of fracture healing.

\section{Introduction}

Bone healing is a complex physiological process and involves numerous mechanisms at tissue and cellular levels. This phenomenon differs from that of soft tissue because of its morphology and composition. Healing of bone is a slow process and therefore requires extra physical and mechanical support which could be external and internal fixations or implants. Amongst the materials available for implant applications the selection of titaniumbased materials for implant, is due to the combination of its outstanding characteristics such as high strength, low density (high specific strength), high immunity to corrosion, complete inertness to body environment, enhanced biocompatibility, low 
modulus and high capacity to join with bone and other tissues (Niinomi, 2001).

A number of biomaterials have shown the ability to induce bone formation when implanted at fracture sites, an ability known as osteoinduction. Such osteoinductive biomaterials hold great potential for the development of new therapies in bone regeneration (Barradas et al., 2011). Tricalcium phosphate believed to be osteoconductive and their small sized particles have interconnected; microporacity offers excellent bio-reabsorbable and biocompatible properties and promote process of remodeling (Erbe et al., 2001). Decellularised bone graft contains natural extra cellular matrix which provides structural support, growth factors and cytokines that are naturally stored within bone matrix to guide bone tissue formation (Gomes et al., 2006).

Haemato-biochemical parameters like haemoglobin, total erythrocyte count, total leukocyte counts and differential leucocyte count included neutrophil, lymphocyte, eosinophil, basophil and monocyte activity and serum calcium, phosphorus and alkaline phosphatase enzyme activity during fracture healing were analyzed and evaluated. Assessment of fracture healing based on fluctuation of haemato-biochemical parameters during fracture healing is still debatable. More ever, there is a paucity of data describing the role of these parameters in healing of fractures. Hence, present study was conducted to evaluate haemato-biochemical parameters during fracture healing in 12 dogs.

\section{Materials and Methods}

Twelve dogs of different breeds of either sex presented to Department of Surgery and Radiology, College of Veterinary Science and A.H., NDVSU, Jabalpur, with the long bone fractures, were selected for the study. Clinical symptoms before surgery were, swelling on affected area, evince crepitating sound and pain on palpation and limping were also recorded.

The radiographs in two standard views were taken to diagnose the fracture and to select optimum titanium pins. Out of twelve animals, six animals had overriding, four animals had multiple and remaining two had oblique fracture of different long bones.

All the twelve animals were randomly divided into three groups. Group I was taken as control in which the internal fixation was done by using titanium pin alone, in group II along with the internal fixation by titanium pin decellularised xenogeneic cancellous bone chip graft (DXBG) was filled at the fracture site and in animals of group III along with the internal fixation with titanium pin the sterile synthetic $\beta$-tricalcium phosphate $(\beta$-TCP) was placed at fracture site. In all the groups, pinning was performed as per the standard procedure described by Singh et al., (2015).

A $5 \mathrm{ml}$ blood was collected from each animal on the day of surgery and further at different time intervals up to $60^{\text {th }}$ post-operative day for haemato-biochemical parameters estimation. The days of blood collection were $0,15,30$, 45 and $60^{\text {th }}$ day for biochemical parameters analysis and on $0,7,15$ and $30^{\text {th }}$ day for haematological parameters respectively. The blood was collected in EDTA vial for haematology and serum clot activator vial for harvesting serum from the blood samples. The collected serum was subjected to estimation of serum calcium, serum phosphorus and alkaline phosphatase.

The data obtained during the experiment were subjected to statistics by one-way analysis of variance (ANOVA) described by Snedecor and Cochran (1994). 


\section{Results and Discussion}

\section{Haematological parameters}

\section{Haemoglobin}

The mean values of haemoglobin showed significant $(p<0.05)$ decrease at 7 day intervals in the animals of all the three groups. However, from 15-30 days values returned to its normal level. The significant decreased might be attributed to presence of more inflammation till $7^{\text {th }}$ day in group I animals than remaining two groups and due to the physical stress at the time of fracture, loss of blood during surgery, as well as haemodilution and anesthesia during internal fixation procedure. The above findings are in accordance with the findings of Tembhurne $e t$ al., (2010) (Table 1).

\section{Total erythrocyte count}

Total erythrocyte count showed nonsignificant decreased on $7^{\text {th }}$ day, followed by increase on $15^{\text {th }}$ and $30^{\text {th }}$ day in group I and III respectively. Whereas, dogs of group II showed non-significant increased on 15 day followed by significant increased $(\mathrm{p}<0.05)$ on $30^{\text {th }}$ day. The transient fall in total erythrocyte count may be attributed to mild hemorrhages during surgical procedure or sequestration of RBC to spleen as opinioned by Lobo et al., (2013). The observations are also correlated with the findings of Aithal et al., (1998) (Table 1).

\section{Total leucocyte count}

The mean leucocyte count expressed a nonsignificant decreasing pattern at most of the operative intervals in all the animals of three groups which was within the reference range as quoted by Aiello and Mays, (1998). This gradual decrease at different post-operative days was indicative of return to normal condition after fracture in dogs. Further, nonsignificantly higher values in all the groups at 0 day may be attributed to the systemic inflammatory changes after fracture as supported by the findings of Toth et al., (2014) who observed an elevated leucocyte count in early post-operative period in beagle dogs (Table 1).

\section{Differential leukocyte count}

\section{Neutrophil}

The mean neutrophil count showed a gradual non-significant decreasing trend in animals of group II and III from 7 to 30 day, while significant increase $(p<0.05)$ was observed in animals of group I from 7 to 15 day followed by significant decrease and value return to its normal range. The significant increase in neutrophil count (\%) in animals of group I may be attributed to extent of trauma leading to inflammation and invasion of other infection according to the findings of Saravanan (2002) and Khan et al., (2011)

Whereas, the neutrophil count was significantly less in group II as compare to group III and I respectively. This might be attributed due to the histocompatible biomaterials used at fracture site reduces inflammatory responses and leads to progressive fracture healing without any exudation (Table 1).

\section{Lymphocyte}

A significant increased $(\mathrm{p}<0.05)$ in lymphocyte count was observed on 7 and 15 day interval in group I, II and III respectively. Thereafter, the values returned to its normal range on 30 day in all the groups.

This can be attributed to relative variation in neutrophil count which increases initially after surgical intervention and further 
activates the production of immune regulatory cytokines by macrophages and monocyte. Cytokines are responsible for activation of adrenal axes and increase production of glucocorticoids, which might be responsible for lyses of lymphoid tissue and circulating lymphocytes (Kaneko, 1997). Khan et al., (2011) also observed a wider observation range of lymphocyte count in stray dogs in Asian continent.

The neutrophil are the first line of cellular defense of the body and leucocytosis (due to neutrophilia and monocytosis - second line of cellular defense), is generally observed during the initial stages of inflammation (Schalm et al., 1975 and Sastry, 1989) (Table 1).

\section{Eosinophil count}

The mean eosinophil count showed nonsignificant difference at different intervals in all animals of three groups.

All the values were within reference range as quoted by Aiello and Mays (1998). Similarly, Zama et al., (1999), also reported nonsignificant variation in eosinophil count during post-operative acupuncture therapy in femoral fracture repair in dogs (Table 1).

\section{Basophil}

The mean basophil count showed a nonsignificant difference among groups or within group at different time interval (Table 1).

\section{Monocyte}

The mean monocyte count showed nonsignificant variations at different time interval in the animals of all the groups according to the Aiello and Mays (1998) and Zama et al., (1999), also reported non-significant variation in monocyte count during fracture healing in dogs (Table 1).

\section{Serum biochemical parameters}

\section{Serum calcium}

The serum calcium level on 15 post-operative days was significantly $(p<0.05)$ less when compared to other post-operative day in all the animals of three groups. The gradual decrease in serum calcium level might be due to deposition of the excessive calcium at the fracture site and further increase in its value on 45 to 60 day attributed to remodeling phase. However, calcium level fluctuation was higher in the animals of group II and III with biomaterial as compare to animals of group I without biomaterial. The above findings are in accordance with the finding of Komnenou et al., (2005) and Rajhans (2013) (Table 2).

\section{Serum phosphorus}

The serum phosphorus showed nonsignificantly decreased on $15^{\text {th }}$ day interval. However, the value of serum phosphorous fluctuated within the normal physiological limits. This might be attributed to osteoclastic activity leading to resorption of dead bone resulting in gradual decrease in serum phosphorous as observed in present study. These results are in agreement with the findings of Pandey and Udapa (1981) and Rajhans (2013) (Table 2).

\section{Alkaline phosphatase}

The serum alkaline phosphatase level was significantly $(\mathrm{p}<0.05)$ increase on 15 postoperative day thereafter it decreases from 45 to 60 day post operatively in all the animals of three group. This may be attributed due to implantation of osteoinductive biomaterials at fracture site, further increases the osteoblastic activity. 
Table.1 Mean \pm SE values of haematological parameters of different groups at different time intervals

\begin{tabular}{|c|c|c|c|c|c|c|}
\hline S.no. & Parameter & Groups & $0^{\text {th }}$ day & $7^{\text {th }}$ day & $15^{\text {th }}$ day & $30^{\text {th }}$ day \\
\hline \multirow[t]{3}{*}{1.} & \multirow{3}{*}{$\begin{array}{l}\text { Haemoglobin } \\
\text { (g/dl) }\end{array}$} & I & $13.05^{\mathrm{a}} \pm 0.37$ & $9.55^{b} \pm 0.56$ & $11.53^{\mathrm{ab}} \pm 0.84$ & $12.05^{\mathrm{a}} \pm 0.82$ \\
\hline & & II & $13.25 \pm 0.45$ & $10.65^{b} \pm 0.52$ & $11.53^{\mathrm{ab}} \pm 0.31$ & $11.95^{\mathrm{ab}} \pm 0.88$ \\
\hline & & III & $13.63^{\mathrm{a}} \pm 0.24$ & $10.28^{b} \pm 0.60$ & $11.90^{\mathrm{ab}} \pm 0.47$ & $11.13^{b} \pm 0.85$ \\
\hline \multirow[t]{3}{*}{2.} & \multirow{3}{*}{$\begin{array}{l}\text { Total erythrocyte } \\
\text { count }\left(10^{6} / \mu \mathrm{l}\right)\end{array}$} & I & $6.31 \pm 0.64$ & $5.99 \pm 0.55$ & $6.11 \pm 0.51$ & $6.52 \pm 0.26$ \\
\hline & & II & $6.19^{b} \pm 0.51$ & $5.84 \pm 0.16$ & $7.17 \pm 0.44$ & $7.65^{\mathrm{a}} \pm 0.76$ \\
\hline & & III & $6.10 \pm 0.25$ & $5.71 \pm 0.74$ & $6.08 \pm 0.18$ & $6.30 \pm 0.42$ \\
\hline \multirow[t]{3}{*}{3.} & \multirow{3}{*}{$\begin{array}{l}\text { Total Leucocyte } \\
\text { count }\left(10^{3} / \mu \mathrm{l}\right)\end{array}$} & I & $14.55 \pm 0.02$ & $14.38 \pm 0.05$ & $14.31 \pm 0.07$ & $14.26 \pm 0.09$ \\
\hline & & II & $13.23 \pm 1.60$ & $11.60 \pm 0.92$ & $11.03 \pm 2.41$ & $10.45 \pm 1.34$ \\
\hline & & III & $14.48 \pm 0.06$ & $14.40 \pm 0.10$ & $14.23 \pm 0.08$ & $13.73 \pm 2.10$ \\
\hline \multirow[t]{3}{*}{4.} & \multirow[t]{3}{*}{ Neutrophil(\%) } & I & $72.30 \pm 1.32$ & $81.00^{\mathrm{Aa}} \pm 0.91$ & $80.00^{\mathrm{Aa}} \pm 6.06$ & $73.50^{\mathrm{Ab}} \pm 3.18$ \\
\hline & & II & $76.00 \pm 4.14$ & $75.25^{\mathrm{B}} \pm 1.84$ & $74.25^{\mathrm{B}} \pm 4.17$ & $67.50^{\mathrm{B}} \pm 3.48$ \\
\hline & & III & $78.75 \pm 1.49$ & $77.50^{\mathrm{B}} \pm 0.22$ & $76.33^{\mathrm{B}} \pm 6.21$ & $75.83^{\mathrm{AB}} \pm 0.30$ \\
\hline \multirow[t]{3}{*}{5.} & \multirow[t]{3}{*}{ Lymphocyte(\%) } & I & $21.25^{\mathrm{b}} \pm 3.38$ & $37.75^{\mathrm{Aa}} \pm 3.01$ & $33.75^{a} \pm 0.85$ & $23.75^{\mathrm{Ab}} \pm 1.89$ \\
\hline & & II & $16.50^{b} \pm 3.43$ & $25.25^{\mathrm{Ba}} \pm 2.43$ & $23.25^{\mathrm{ab}} \pm 0.63$ & $17.25^{\mathrm{Bb}} \pm 1.11$ \\
\hline & & III & $14.75^{c} \pm 1.89$ & $34.25^{\mathrm{Aa}} \pm 1.65$ & $33.75^{\mathrm{a}} \pm 0.85$ & $24.50^{\mathrm{Ab}} \pm 1.04$ \\
\hline \multirow[t]{3}{*}{6.} & \multirow{3}{*}{$\begin{array}{l}\text { Eosinophil } \\
\operatorname{count}(\%)\end{array}$} & I & $1.50 \pm 0.87$ & $2.00 \pm 0.71$ & $0.25 \pm 0.25$ & $3.50 \pm 1.85$ \\
\hline & & II & $1.25 \pm 0.75$ & $0.50 \pm 0.50$ & $0.75 \pm 0.48$ & $1.75 \pm 0.85$ \\
\hline & & III & $0.25 \pm 0.25$ & $0.75 \pm 0.48$ & $1.75 \pm 0.85$ & $2.50 \pm 1.26$ \\
\hline \multirow[t]{3}{*}{7.} & \multirow[t]{3}{*}{ Basophil(\%) } & I & $0.16 \pm 0.16$ & $0.00 \pm 0.00$ & $0.00 \pm 0.00$ & $0.16 \pm 0.16$ \\
\hline & & II & $0.00 \pm 0.00$ & $0.00 \pm 0.00$ & $0.00 \pm 0.00$ & $0.00 \pm 0.00$ \\
\hline & & III & $0.00 \pm 0.00$ & $0.00 \pm 0.00$ & $0.00 \pm 0.00$ & $0.00 \pm 0.00$ \\
\hline \multirow[t]{3}{*}{8.} & \multirow[t]{3}{*}{ Monocyte(\%) } & I & $3.25 \pm 0.48$ & $2.50 \pm 0.29$ & $3.00 \pm 0.91$ & $2.50 \pm 0.96$ \\
\hline & & II & $1.25 \pm 0.63$ & $0.75 \pm 0.48$ & $0.75 \pm 0.48$ & $2.00 \pm 0.71$ \\
\hline & & III & $0.25 \pm 0.25$ & $0.50 \pm 0.29$ & $1.00 \pm 0.71$ & $1.25 \pm 0.48$ \\
\hline
\end{tabular}

Mean value within interval (lowercase) with different superscript differed significantly $(\mathrm{p}<0.05)$

Table.2 Mean \pm SE values of serum biochemical parameters of different groups at different time intervals

\begin{tabular}{|c|c|c|c|c|c|c|c|}
\hline S.no. & Parameter & Groups & $0^{\text {th }}$ day & $15^{\text {th }}$ day & $30^{\text {th }}$ day & $45^{\text {th }}$ day & $60^{\text {th }}$ day \\
\hline \multirow[t]{3}{*}{1.} & \multirow{3}{*}{$\begin{array}{l}\text { Serum } \\
\text { calcium } \\
(\mathrm{mg} / \mathrm{dl})\end{array}$} & I & $9.56^{\mathrm{ab}} \pm 0.23$ & $7.59^{\mathrm{ab}} \pm 0.47$ & $9.66^{\mathrm{ab}} \pm 0.77$ & $10.50^{\mathrm{ab}} \pm 0.24$ & $9.85^{\mathrm{a}} \pm 0.62$ \\
\hline & & II & $11.26^{\mathrm{b}} \pm 0.62$ & $7.00^{c} \pm 0.46$ & $7.83^{c} \pm 0.35$ & $10.39^{b} \pm 0.42$ & $10.90^{\mathrm{a}} \pm 0.29$ \\
\hline & & III & $10.07^{\mathrm{a}} \pm 0.49$ & $7.10^{b} \pm 0.43$ & $9.59^{\mathrm{a}} \pm 0.99$ & $10.05^{\mathrm{a}} \pm 0.47$ & $10.79^{\mathrm{a}} \pm 0.42$ \\
\hline \multirow[t]{3}{*}{2.} & \multirow{3}{*}{$\begin{array}{c}\text { Serum } \\
\text { phosphorous } \\
(\mathbf{m g} / \mathrm{dl})\end{array}$} & I & $3.89 \pm 0.70$ & $3.17 \pm 0.46$ & $4.38 \pm 0.48$ & 3.8 & $4.54 \pm 0.41$ \\
\hline & & II & $4.22^{a} \pm 0.46$ & $2.27^{c} \pm 0.42$ & $2.89^{b c} \pm 0.20$ & $3.59^{\mathrm{ab}} \pm 0.21$ & $4.59^{\mathrm{a}} \pm 0.52$ \\
\hline & & III & $5.91 \pm 3.43$ & $3.73 \pm 1.18$ & $4.79 \pm 1.49$ & $5.21 \pm 1.35$ & $5.30 \pm 0.79$ \\
\hline \multirow[t]{3}{*}{3.} & \multirow{3}{*}{$\begin{array}{c}\text { Alkaline } \\
\text { phosphatase } \\
\text { (IU/L) }\end{array}$} & I & $108.08 \pm 7.0$ & 112. & 131 & 116. & $111.6 \pm 12.2$ \\
\hline & & II & $128.7^{\mathrm{b}} \pm 12.3$ & $172.8^{\mathrm{ab}} \pm 20.2$ & $197.2^{a} \pm 22.1$ & $147.13^{b} \pm 2.9$ & $145.75^{b} \pm 9.9$ \\
\hline & & III & $122.8^{b} \pm 9.6$ & $168.73^{\mathrm{ab}} \pm 4.9$ & $191.2^{\mathrm{a}} \pm 41.9$ & $148.8^{\mathrm{ab}} \pm 12.2$ & $140.8^{\mathrm{ab}} \pm 11.1$ \\
\hline
\end{tabular}

Mean value within interval (lowercase) with different superscript differed significantly $(\mathrm{p}<0.05)$ 
As osteoblast secretes large quantities of alkaline phosphatase, which is involved in the process of matrix formation and its mineralization. Alkaline phosphatase is believed to either increase the concentration of local inorganic phosphate or inorganic pyrophosphate that is necessary for fracture healing (Volpin et al., 1998) (Table 2).

On the basis of above findings it can be concluded that, changes in the haematobiochemical parameters at different postoperative days is directly correlated with the different phases of fracture healing.

\section{References}

Aiello, S.E. and Mays, A. (1998). The Merck Veterinary Manual, $8^{\text {th }}$ Edn., Merck \& Co., Inc, Whitehouse station, New Jersey, pp 2188-2195.

Aithal, H.P., Singh, G.R. and Bisht, G.S. (1998). Incidence of fractures in different domestic animals - A twenty year survey analysis. In: $22^{\text {nd }}$ Indian Society for Veterinary Surgery Symposium, Bhubneshwar, 5-7 November, pp. 30-32.

Barradas, M.C., Yuan, H., VanBlitterswijk, C.A. and Habibovic P. (2011). Osteoinductive biomaterials: current knowledge of properties, experimental models and biological mechanisms. European Cells and Materials, 21: 407429.

Erbe, E.M., Marx, J.G., Clineff, T.D. and Bellincampi, L.D. (2001). Potential of an ultraporous $\beta$-tricalcium phosphate synthetic cancellous bone void filler and bone marrow aspirate composite graft. European Spine Journal, 10: 141-146.

Gomes, M.E., Bossano, C.M., Johnston, C.M., Reis, R.L. and Mikos, A.G. (2006). In vitro localization of bone growth factors in constructs of biodegradable scaffolds seeded with marrow stromal cells and cultured in a flow perfusion bioreactor. Tissue Engineering, 12(1): 177-188.

Komnenou, A., Karayannopoulou, M., Polizopoulou, Z.S., Constantinidis, T.C. and Dessiris, A. (2005). Correlation of serum alkaline phosphatase activity with the healing process of long bone fractures in dogs. Veterinary Clinical Pathology, 34: 35-38.

Kaneko, J. (1997). Carbohydrate metabolism and its decrease: blood glucose in animals. Text Book of Clinical Biochemistry of Domestic Animals. $5^{\text {th }}$ Edn., Elsevier publishers, Philadelphia, U.S.A., pp64.

Khan, S.A., Epstein, J.H., Olival, K.J., Hassan, M.M., Hossain, M.B., Rahman, K.B.M.A., Elahi, M.F., Mamun, M.A., Haider, N., Yasin, G. and Desmond, J. (2011). Hematlogy and serum chemistry reference values of stray dogs in Bangladesh. Open Veterinary Journal, 1: 13-20.

Lobo, D., Lewington, A.J.P. and Allison, S.P. (2013). Basic Concepts of Fluid and Electrolyte Therapy. Bibliomed, Germany, pp9-22.

Niinomi, M. (2001). Titanium based biomaterials, the ultimate choice for orthopaedic implants- A review. Metallurgical and Materials Transactions, 32: 477-86.

Pandey SK, Udapa KN. Effect of growth hormone on biochemical response after fracture in dogs. Indian Journal of Veterinary Surgery. 1981; 1(2):73-78.

Rajhans, M. (2013). Stabilisation of splinters of long bone fracture in dogs. M.V.Sc. \& A.H. thesis (Surgery and Radiology), Nanaji Deshmukh Veterinary Science University, Jabalpur.

Saravanan, B., Maiti, S.K., Hoque, M., Aithal, H.P. and Singh, G.R. (2002). Management of comminuted femoral fracture by different internal fixation 
techniques in dogs. Indian Journal of Animal Science, 72: 1104-1108.

Sastry, G.A. (1989). Veterinary Clinical Pathology. $3^{\text {rd }}$ Edn., C.B.S. Publishers and Distributors Pvt. Ltd., Delhi. pp807.

Schalm, O.W., Jain, N.C. and Carrol, E.J. (1975). Veterinary Haematology. $3^{\text {rd }}$ Edn., Lea and Febiger, Pheladelphia. pp807.

Singh, R., Chandrapuria, V.P., Shahi, A., Bhargava, M.K., Swamy, M. and Shukla, P.C. (2015). Fracture occurrence pattern in animals. Journal of Animal Research, 5(3): 611-616.

Snedecor, G.W. and Cochran, W.G. (1994). Statistical Methods, $8^{\text {th }}$ Edn., Oxford and IBH Publishing Co., pp291-293.

Tembhurne, R.D., Gahlod, B.M., Dhakate, M.S., Akhare, M.S., Upadhaye, S.V. and Bawasker, S. (2010). Management of femoral fracture with the use of horn peg in canine. Veterinary World, 3(1): $37-41$.

Toth, C., Klaril, Z., Kiss, F., Toth, E., Hargitai, Z. and Nemeth, N. (2014). Early postoperative changes in haematological, erythrocyte aggregation and blood coagulation parameters after unilateral implantation of polytetrafluoroethylene vascular graft in the femoral artery of Beagle dogs. Acta Cirurgica Brasileira, 29(5): 320-327.

Volpin, G., Rees, J.A. and Ali, S.A. (1998). Distribution of alkaline phophatase activity in experimentally produced callus in rats. American Journal of Bone and Joint Surgery, 68: 629-634.

Zama, M.M.S., Gupta, O.P., Singh, G.R. and Swarup, D. (1999). Postoperative acupuncture therapy in fracture of femur. Indian Journal of Veterinary Surgery, 20(2): 86-87.

\section{How to cite this article:}

Astha Chaurasia, Shobha Jawre, Randhir Singh, Apra Shahi, Rekha Pathak,, Babita Das and Naveen Kumar Verma. 2019. Evaluation of Haemato-Biochemical Parameters using Different Biomaterials in Fracture Healing of Dogs. Int.J.Curr.Microbiol.App.Sci. 8(05): 2265-2271. doi: https://doi.org/10.20546/ijcmas.2019.805.266 